\title{
A BIBLIOGRAPHY OF ADMINISTRATIVE AND TECHNICAL COMHUNICATION IN CANADA: PART II
}

\author{
Jennifer J. Connor
}

The following list includes sources compiled since the publication of a bibliography in Technostyle 4(Spring 1985):20-35. Specifically, it provides a wider coverage of professional periodicals in fields such as business, accounting, and medicine, and it completes an index of Technostyle to 1985. Like the earlier bibliography, this one includes a few general items on writing and grammar for reference; and, consistent with the earlier collection policy, this list includes works which were written by or for Canadians, but which themselves may not be overtly Canadian in content. Both bibliographies should be consulted together for completeness. For further information on works published in French, readers should consult Joan E. Pavelich's bibliography in Technostyle 1 (Summer 1982):13-16.

Abadie, $V$. "La communication interne pré-requis à un bon climat organisationnel." Commerce 81(Fevrier 1979):60-64;66+.

Ainslie, D.S. "Good Management Means Communication." Dimensions in Health Service 53(October 1976):30-31.

Allaire, Denis. Ëtude sur la Production de Lettres Avec Copie par Editeur de Textes. [Québec]: Ministere des Affaires Sociales, Centre de documentation, 1981 .

"Are You a Good Listener?" Western Business \& Industry 39(February 1965):26-27.

Armstrong, H.L. "Communications: Industry's Biggest Problem Today." Canadian Personnel and Industrial Relations 12(July 1965):8-9.

Arsenault, A. "Communication." Union Médicale du Canada 107(September 1978): 781-82.

"The Art of Communication." Canadian Chartered Accountant 87(August 1965) :83-85.

Ashby, David. "Good Manuals Produce Productivity." Canadian Office 13(October 1982):28-29.

-...-. "Producing Good Procedures Manuals." Proceedings of ARMA 2nd Canadian Conference on Records Management. Montreal: Association of Records Managers and Administrators, 1982. Pp. E11-9/5. 
Ayers, David. "Managerial Technical Writing." Technostyle 1(Fall

Baker, Victor G. "How's Your Public Speaking?" Canadian Business 45 (October 1972):46-48.

Bala, S. "Operation Communication." Canadian Nurse 72(November 1976): 37-39.

Bèlanger-Goulet, Hēlène. Guide pour manuel de normes et pratiques de gestion. Dans Guide de Normalisation de Techniques en Archives Médicales. Rock Forest, Quëbec: Association québécoíse des archivistes mëdicales, 1982.

Bell, James B., and Edward P.J. Corbett. The Little English Handbook for Canadians. Toronto: Wiley, 1977.

Bienvenue, Andre. "Principles of Forms Design." Canadian Office 10 (October 1979):34.

Blicq, Ron S. "Job Hunting: Sharpening Your Competitive Edge." IEEE Transactions on Professional Communication PC-27(December 1984):201-10.

.-.--. "The Importance of Consulting to the Teacher of Technical Writing." Technostyle 1(Spring 1982):25-28.

-..--. "The Teacher of Technical Writing in Canada: A Profile." Technostyle 4(Spring 1985):1-19.

Bogdanowicz, Maureen S. Write, Wrote, Written. 2nd ed. Dubuque, Iowa: Kendall/Hunt, 1985.

Bois, J.S.A. "The Art of Listening." Canadian Business 25(May 1952): $31 ; 86-88$.

Borwick, Irving. "Plan for Communicating." Canadian Business 42 (May 1969) : 48-50;53.

Bossé-Andrieu, Jacqueline. "Rédaction Spécialisẻe et Utilisation du Dictionnaire." Technostyle 4(Spring 1985):47-56.

Brassard, Gilles. "Translations: A Necessity Becomes Big Business." Canadian Business 47(September 1974):37;48.

Brent, Douglas. Review of Principles of Communication for Science and Technology, by Leslie A. OTsen and Thomas N. Huckin. Technical Writing Teacher 13(Winter 1986):84-88. 
Briens, Cedric, and Charles Durand. "Exemples des Roles Respectifs de I'Anglais et du Français dans la vie Professionelle d'Ingenieurs en France, au Quëbec, au Canada Anglais et Aux États-Unis." Technostyle 1(Fall 1982):10-12.

Brock, P. "Dear Sir." Western Business \& Industry 37 (January 1963):20-21.

Brocklehurst, M. English for the Business World. Montreal: MCGraw-Hill, 1979.

Brown, D. "Why Businessmen Can't Write." Financial Post Magazine 75(March 1981):51-54.

Buetow, C.P. "Make Those Manuals Meaningful." Office Equipment and Methods 17 (September 1971):84-85.

Bureau de Normalisation. Imprimes Administratifs: Guide Pour la Présentation des Lettres d’Affaires. 2e éd. Québec: Bureau de Normalisation, 1980.

"Can You Read All the Writing on Your Forms?" Office Equipment and Methods 17 (June 1971):54.

Canning, H. "Nine Ways to Improve Your Writing and Speaking." Executive 12(July 1970):31-32.

Carty, J.M. "Effective Report Writing." Canadian Chartered Accountant 94(April 1969):260-62.

Champagne, Jean-Paul. "Le Terminologue/The Terminologist." Technostyle 4 (winter 1985):24-30.

Chartrand, M. "Tout le monde parle, personne n'ècoute." Commerce 82 (Fevrier 1980):104.

Cherry, P.G. "How to Improve Your Correspondence." Canadian Business 11 (June 1938):40-41;96.

Chisling, John. "Binders Can Cut Your Print Costs." Canadian Office 15 (March 1984):30.

"CLA Guidelines on Non-sexist Language." Canadian Library Journal 33(August 1976):369-71.

Clarke, Doris C. "Good Works Need Good Words." Canadian Business 27 (April 1954):34-35;40-41.

Clarke, F.R. "Watch Your Language." Canadian Business 23(January 1950):34-35. 
Cohen, Robert M. "10 Ingredients of Successful Written Presentations." CA Magazine 117(December 1984):64-66.

Collins, James. "Do I Write a Good Business Letter?" Canadian Business 15(June 1942):66;71.

Commission de Rēforme du Droit au Canada. La rẻdaction française des lois. Ottawa: Approvisionnements et Services Canada, 1982.

Communications Canada, J.W. Tombaugh, and Richard F. Dillon. La conception des guides d'utilisation du matériel bureaucratique: analyse de la documentation existante. Co. 22-39. Ottawa: 1983.

-...-. The Design of User Manuals for Office Systems: A Review of the Literature. Ottawa: 1983.

Connor, Jennifer J. "A Bibliography of Administrative and Technical Communication in Canada." Technostyle 4(Spring 1985):20-35.

-...-. "The Formal Report: A Comparison of Instructional Contexts." Technostyle 4(Winter 1985):16-23.

-.--. "Submissions in the Technical Writing Course: Towards Ensuring Their Originality." The English Quarterly 18(Summer 1985):53-56.

Connor, Richard A., Jr., and J. Larry White. "Write a Better Management Letter." CA Magazine 108(May 1976):58-60.

"Constructing Effective Letters." Western Business \& Industry 36(May 1962):70.

Cope, M. "Communications: They're Moving from Fair to Lousy." Executive 11(September 1969):56-57.

Crawley, David. "The Office Manual." Canadian Business 25(November 1952): $31 ; 52-54$.

Cryderman, Paula. Developing Policy and Procedure Manuals. Ottawa: Canadian Hospital Association, 1981.

"How to Keep Your Manuals Up to Date." Health Care 24(June 1982):21-22.

-.---. "How to Set Up a Policy and Procedures Manua1." Dimensions in Health Service 57 (November 1980):23-27.

-..--. "Manual Coordinator: Luxury or Necessity?" Dimensions in Health Service $58($ September 1981):42-43. 
Currie, C. "Communicating in an Automated Environment." Canadian Banker 91 (December 1984):18-21.

Curtis, Fred. "A Checklist for the Writing and Presentation of Environmental Assessment (EA) Reports." Canadian Geographer 26(Spring 1982):64-70.

Davis, Richard M. "Technical Writing: Who Needs It?" Technostyle 1(Spring 1982):13-19. [Reprinted from Engineering Education November 1977]

Department of National Defence. A-AD-121-C01/FP-000, DND Administrative and Staff Procedures Manual, Staff Procedures and Military Writing for the Canadian Forces. Volumes 3 and 4, 1974, 1979, 1984.

Després, R. "L'importance de la communication en gestion universitaire." Cost and Management 52(March-April 1978):40-45.

The Directory: How to Plan and Produce a Directory. [Toronto]: Ministry of Culture and Recreation, Community Information Services, [1976].

Dhalla, N.K. "Developing That All-Important Empathy." Canadian Business 44(December 1971):23;26-27.

-..-. "How to Arouse and Hold Attention." Canadian Business 44 (November 1971):48-50;52-54.

-...-. "Look Who's Talking. Part I." Canadian Business 44(February 1971):18-20;22.

-.-.-. "More Useful Guideposts. Part II." Canadian Business 44 (February 1971):24-26;28.

Dingwall, D.E. "Audio-visual Aids: A Practical Way to Sell." Canada Commerce 138(April 1974):28.

Dixon, C.M., et al. "Communication: Key to Infection Control." Dimensions in Health Service 60(September 1983):19-22.

Drapeau, Arnold. "La Contre-Attaque du Français Scientifique." Technostyle 1(Spring 1982):29-34.

Ede, Lisa, and Andrea Lunsford. "Research Into Collaborative Writing." Technical Communication 32, No. 4(Fourth Quarter 1985):69-70.

Emanuel, E. "Musings on Communication." Canadian Medical Association Journal 118(5)(March 4, 1978):588-90. 
Emeyriat, Carolynn. "A Survival Course in Aeronautical Report Writing for French-Canadian Aircraft Maintenance Technicians." Technostyle 4(Summer 1985):11-14.

"English for Engineers." Canadian Business 33(March 1960):28-30.

"Firm Teaches Managers to Write Letters." Financial Post Magazine $77($ March 26, 1983):17.

Fisher, J. "Call to All Communicators to Join the Plain English Movement." Marketing 86(July 6, 1981):21-22;24.

Foyle, Joseph. "How Better Reading Skills Can Cure Executive Stress." Canadian Business 48(September 1975):40;43-44.

Frederick, J. George. "Faster Reading . . Greater Productivity." Canadian Business 26(May 1953):32-33;94-95.

...-... "Put It In Writing." Canadian Business 22(March 1949):84-86.

Gabor, T., and C.H.S. Jayewardene. "The Pre-sentence Report as a Persuasive Communication." Canadian Journal of Criminology 20(January 1978):18-27.

Gardiner, Diane. "Technical Writing in British Columbia. Where Is It?" Technostyle 1(Summer 1982):2.

"General Correspondence." Western Business \& Industry 36(March 1962):78.

Gibson, Alice L. "CAI: Yes or No?" Technostyle 4(Summer 1985):38-43.

"Teaching Business Communications Students to Write as Readers." Technostyle 4(Spring 1985):57-62.

Godbout, Alain. "Une note d'accompagnement au ministre." Canadian Public Administration 27(Fall 1984):437-41.

Godfrey, David W.H. "Communication for Aerospace Students: A Polytechnical Approach." Technostyle 4(Summer 1985):15-27.

Godstone, J. "Are You Easy to Read?" Western Business \& Industry $39($ March 1965):35-37.

Goodman, Eileen. "How to Write Business Reports for Management Action." Canadian Business 34(February 1961):48-50;52-54.

Gosselink, Robert N. "The Use of Wordprocessing and Writer's Computer Programs in Report Writing." Technostyle 4(Summer 1985):28-37.

Gourlay, Glen T. "Financial Reports for Employees." CA Magazine 117 (April 1984):60-64. 
Graham, C.R. "Specific Business Writing Problems." Industrial Canada 65 (January 1965):27-30. "Who's Afraid of Writing?" Industrial Canada 65(November
1964):37-40.

Grass, B. "Organization Talks to Itself." C-I-L Oval 39(Spring 1970):4-5.

Greenwood, D.C. "Business Letters the Modern Way." Business Quarterly 22 (Spring 1957):45-52.

Grossman, E. "Bringing Listening into Question." Dimensions in Health Service 55(April 1978):38-39.

Grossman, H.K. "Organization and Preparation of Procedure Manuals." Canadian Chartered Accountant 83(1963):360-61.

Groves, C. "English for Engineers." Canadian Business 33(March 1960): 28-30.

Guernier, Claude, Gaston Pouliot, Rolland Viau, et Fred Bassal. "L'Importance de la Communication Ecrite et Verbale Chez 1'INGENIEUR." Technostyle 1(Spring 1982):3-12.

Guertin, J. "La perception selective dans le processus de communication." Commerce 68(Juin 1966):23-26.

Guetta, Pauline. "Employee Publications: The Good, the Bad and the Beautiful." Canadian Business 46(April 1973):24-26;31.

Hanft, P., and M. Roe. "How To Write Well in Business." CA Magazine 111 (May 1978):72-74; (July 1978):46-47.

Harley, Dale, and Ken Kelly. "Making Communications Effective: A Case Study." Optimum 15(3)(1984):48-67. [With French summary.]

Hasley, Alex R. "5 Steps to Better Business Letters." Canadian Business 22(July 1949):38;60.

-..--. "Trainees Build the Best Manuals." Canadian Business 25(March 1952):52-53;65.

Hill, 0.M. "How to Win World Markets: Four Principles of Export Correspondence." Foreign Trade 125(May 14, 1966):27-30.

"Let's Talk Export Correspondence." Foreign Trade 111 (May 23, 1959):9-12.

Hil1, P.L. "Internal Newsletters: The Medium is the Message." Dimensions in Health Service 61 (June 1984):31. 
Hi11, P.L. "Media: Making Sure They Get the Message." Dimensions in Health Service 60(April 1983):31-32.

Hockman, John. "A Checklist for Forms Design." Management Review (October 1971):26-30.

Hodges, John C. and Mary E. Whitten. Harbrace College Handbook for Canadian Writers. 2nd ed. Don Mills: Harcourt Brace Jovanovich Canada, 1985.

Hogue, J.P. "La communication." Commerce 67(Janvier 1965):19-20.

-.-.-. "Reflexions sur la communication." Commerce 69(Fevrter 1967): 15-16.

Holobow, Marian. "Meeting a Need (An Administrative Writing Course for ESL Writers)." Technostyle 4(Winter 1985):36-51.

Horguelin, Paul A. "Le Contrôle de la Qualité en Comnunication Ecrite: Approche Pëdagogique." Technostyle 4(Summer 1985):1-6.

-..--.. Pratique de la rëvision. 2e ëd. Montrēal: Linguatech, 1985.

-.---.. Structure et style. Montréal: Linguatech, 1985.

Hosington, B., et $P_{\text {. Horguelin. A Practical Guide to Bilingual }}$ Revision. Montréal: Linguatech, 1980.

"How to Read Clinical Journals: I. Why to Read Them and How to Start Reading Them Critically." Canadian Medical Association Journal 124(5) (March 1, 1981):555-58.

"How to Write the Letter Applying for a New Job." Business Woman (April 1928): $16 ; 33$.

Howson, A.H. "The Art of Effective Report Writing." Canadian Chartered Accountant 87(September 1965):165-68; reprinted in Canadian Business 39 (October 1966): 96-98; 101 .

Hull, R.P., and J.0. Everett. "Relevance--Its Connection with Communication." Cost and Management 58(January-February 1984): 38-41.

Jean, Paul. "Gestion du personnel: On ne peut pas plus se passer d'un manuel de directives." Le Bureau (Mars-Avril 1983):34+.

Johnson, Duane M. "Prevent Misunderstandings in Your Practice with Clear-Cut Personnel Policies." Canadian Doctor 49(March 1983):62.

Jordan, Michael P. "Complex Lexical Cohesion in the English Clause and Sentence." Tenth LACUS Forum 1983, ed. Alan Manning, Pierre Martin and Kim MCCalla. Columbia, South Carolina: Hornbeam Press, 1984. Pp. 224-34. 
Jordan, Michael P. "Some Clause-Relational Associated Nominals in Technical English." Technostyle 4(Spring 1985):36-46.

"Systems of Logic in Technical Writing." Technostyle 4(Winter 1985):1-6.

-.--. "Structure, Style and Word Choice in Everyday English Texts." IESL TalK 15(182), (1984):60-67.

-.--... "Teaching Technical Report Writing--Some Recent Advances." Journal of Technical Writing and Communication 5(3), (1975).

----. "The Genre of Technical Description." Technical Writing Teacher 13, No. 1 (Winter 1986):42-50.

Kanary, Reynolds. "Developing a Technical Writing Programme." Technostyle 4(Sumner 1985):7-10.

Kaufman, J.M. "Are You Getting Full Value Out of Your Reports?" Canadian Business 49(March 1976):64-68.

Korneluk, Greg. "A Manual Can Help Your Practice Maintain Consistency of Patient Services." Canadian Doctor 49(May 1983):16-18.

----. "How to Write Patient Information Booklets." Canadian Doctor 45(December 1979):40-48.

"Job Descriptions are Key to Your Practice Efficiency." Canadian Doctor 48(November 1982):63-65.

-.--. "Regular Meetings Can Unite Your Practice Team." Canadian Doctor 49(June 1983):23-25.

"Write an Office Procedure Manual." Canadian Doctor 44(April 1978): 44-50.

Lafrance, J.G. "La présentation de votre correspondance." Commerce 68(Mars 1966):80-81.

Laliberté, Robert G. "Management and the Action Presentation: A Process Model." Optimum 15 (3)(1984):68-92. [With French summary.]

Law, Carl E., and Bernard P. Queenan. "An Introduction to Audio/Visual Techniques." Canadian Business 49(October 1976):58-62.

Leathem, R.M. "Communications--Key to Industrial Harmony." Industrial Canada 69(September 1968):23-27.

"Letter Improvement Programs Save Time and Money." Canadian Business 28 (October 1955):88;90. 
Leury, Edouard et Marcel Pillaud. Rédaction administrative. Ottawa: Commission de la Fonction publique du Canada, Bureau des langues, 1971. 8 vols.

Levin, J. "Getting the Story Across." Industrial Canada 71(February 1971):36-38.

"Problems of Corporate Communication." Industrial Canada 71 (January 1971):23-26.

Levoy, R.P. "How the Right Words Can Make the Wrong Impression." Canadian Veterinary Journal 19(1)(January 1978):27.

Lewis, W.B. "Communication of Science." Proceedings and Transactions. Executive Secretary, Royal Society of Canada. 4th ser. 14(1976):315-20.

Lilley, Wayne. "Newsletters: The Invisible Press." Canadian Business 51 (March 1979):68-71;74.

Logan, Fritz J. "Prairie Pointsmanship: Here's How." Technostyle 1 (Fall 1982):15-23.

Louks, George. "Technical Communications at Saskatchewan Technical Institute, Moose Jaw." Technostyle 1(Spring 1982):21-23.

Love, S.F. "Learn to Communicate with Your Engineers." Canadian Business 48(June 1975):64-67.

Mackinnon, Ian. "Better Forms Design Can Improve Your Agency's Function and Image." Canadian Insurance 83(September 1978):18-20.

Mair, Alex. How to Speak in Public. Edmonton: Hurtig, 1985.

Mansbridge, S.H. "The Question of Effective Communication." Optimum $3(4)(1972): 73-74$.

Martin, J.C. "Parler le langage de l'argent." Commerce 80(Septembre 1978):127-28.

Martin, Ronald. "The Four Barriers to Communications." Office Administration [16](December 1970):6.

McCormick, W.O. "Present Your Paper to Listeners Not Readers: Tips on Talks." Canadian Medical Association Journal 121(9)(November 3, 1979) :1304-12.

Menkus, Belden. "Good Directives the Key to Better Communication." Office Administration 15(April 1969): \$22-23. 
Miles, Leslie L.H. "Guideposts to Effective Communication in a Company." Canadian Business 34(August 1961):62-65.

Ministère des Affaires Sociales. Guide de Preparation Pour un Rapport. Québec: Ministère des Affaires Socíales, 1977.

-.---. Rẻdaction et Présentation des Circulaires. Quëbec: Ministère des Affaires Sociales, 1981.

Ministère des Transports. Guide de Rédaction et de Présentation des Rapports: Rapport d'Etude. Quebec: Ministère des Transports, 1982.

Mitchel1, A.H. "Modernize Your Business Letters." Canadian Business 19 (August 1946):30;78-82.

Montin, Karin. "From Translator to Technical Writer: A Small Leap." Technostyle 2(Spring 1983):[6-8].

Morgan, P.P. "A Cornucopia of Words." Canadian Medical Association Journal 129(7)(October 1, 1983):676.

-.---. "Author, Editor and Reviewer: How Manuscripts Become Journal Articles." Canadian Medical Association Journal 124(6)(March 15, 1981):664-66.

-----. "How to Get a Rejected Manuscript Published." Canadian Medical Association Journal $133(12)$ (July 15, 1985):86-87.

-.---. "How to Write a Letter to the Editor that the Editor will Want to Publish." Canadian Medical Association Journal 132(12)

(June 15, 1985) :1344.

-..--. "Perfecting the Manuscript: Getting the Right Words in the Right Place." Canadian Medical Association Journal 128(7)

(Apri1 1, 1983):769;773.

Mulcahy, Gertrude. "Engagement Letters." Canadian Chartered Accountant 102 (Apri1 1973):51-54; French trans., 68-71.

Ouimet, D. "Un pas pour s'organiser--les documents." Commerce 81 (Avril 1979):38-40;42.

Ormsby, Bill. "A Businessman's Guide to the Fine Art of Listening." Canadian Business 33(February 1960):82-84;86.

Painchaud, Louis, et Pierre Collinge. "Rëdaction-Recherche, Un Nouveau Programme Universitaire." Technostyle 1(Summer 1982):3-6.

Paine, Robert. "Informal Communication and Information-Management." Canadian Review of Sociology and Anthropology $7(3)(1970): 172-88$. 
Panet-Raymond, R. "Les reseaux de communication d'une entreprise." Optimum 3(1)(1972):28-35.

-.--- "Une nouvelle technique d'analyse des organisations: les communications dans l'entreprise." Commerce 73(Septembre 1971):50-55.

Pavelich, Joan E. "Rédaction Administrative." Technostyle 2(Spring 1983):14-21.

-.--. "Vous Cherchez des Manuels de Rëdaction?" Technostyle 1(Summer 1982):13-16.

Perigoe, J. Rae, and Lillian Perigoe. Message and Meaning: Canadian English at Work. Scarborough, Ontario: Prentice-Hall, 1974.

Poland, F. "Science Writing in Canada: Results of a Survey Discussed." [Ministry of State for Science and Technology Seminar] Science Forum 7(June 1974):13-14.

Pollock, Ted. "Put Your Ideas Across--Effectively!" Office Administration 11(September 1965):39;56-58.

Poulton, Terry. "Company Newsletters: Is Video a Better Medium for the Message?" Canadian Business 52(June 1979):24-26.

The Printed Word: How to Produce Printed Information Material. Information Services, [1976].

Quinn, Robert. "Your House Organ." Canadian Business 26(July 1953):36-37;84-85.

Rakoczy, M. "Bridging the Gap in Communication." Dimensions in Health Service 59 (March 1982):16-17.

Rapsey, K.H. "Engineering Report as a Form of Communication." Industrial Canada 69(March 1969):24-28.

Ricks, D.M. "Good Writing? Certainly It Can Be Taught." Canadian Personnel and Industrial Relations 19(0ctober 1972):49-52.

Ritter, Bess. "Cut Correspondence with a Form Letter." Office Equipment and Methods 19(January 1973):34.

Rodier, Felix C. "Effective Communication--A Gap in the Salesman's Curriculum." Canadian Business 34(May 1961):106-12.

Rodman, Lilita. "Advanced Technical Writing: The Student as Investigator." Technostyle 4(Winter 1985):7-15. 
Rodman, Lilita. "How Graphics Affect Technical Discourse." Proceedings 31st Conference on College Composition and Communication: Technical Communication Sessions, ed. John A. Muller (Association of Teachers of Technical Writing, 1980), pp. 198-203.

-...-. "Levels of Abstraction in the Graphic Mode." Teaching Technical Writing: Graphics, ATTW Anthology No. 5, ed. Dixie Elise Hickman (St. Paul, MN: Association of Teachers of Technical Writing, 1985), pp. 1-9.

-.---. "The Passive in Technical and Scientific Writing." ERIC Reports, ED 208 421, March 1981, 13 pp.; reprinted in Journal of Advanced Composition 2(1981):165-72.

----. "Strategies for Removing Ambiguity in Technical Writing." ERIC Reports, ED 172 224, April 1979, 13 pp.

-...-. "Teaching the Formal Report: The First Units." Technostyle 2(Spring-1983):[1-5].

Rogers, David R. "Français des Affaires." Technostyle 2(Summer 1983): 13 .

Roland, C.G. "Thoughts About. Medical Writing. XXXXII. Verify Your References." Anesthesia and Analgesia (Cleveland) 55(5) (September-0ctober 1976):717-18.

"Rout ine Reports--Who Needs Them?" CGA Magazine 12(March 1978):4-7.

Rozorsky, L.E. and F.A. "Put Less Talk and More Action into Your Meetings." Canadian Doctor 49(February 1983):59-60.

Safran, Sandra. "Feedback Frustration." (Western Management Case Material). London, Ontario: School of Business Administration, University of Western Ontario, 1983.

-----. "Frontier Insurance Company." (Western Management Case Material). London, Ontario: School of Business Administration, University of Western Ontario, 1983.

"Northern Systems Services." (Western Management Case Material). London, Ontario: School of Business Administration, University of Western Ontario, 1983.

Salter, M. "Many Managers Need to Learn Writing Skills." Financial Post Magazine 77 (October 1, 1983):15.

--.--. "Newsletter Vital Tool to Maintain Morale." Financial Post Magazine 77 (January 22, 1983):13.

Saunders, A.L. "Ability of a Salesman to Communicate." Industrial Canada 66(August 1965):35-36;41-42; 66(September 1965):45-48. 
Sawatsky, J.C. "Purpose of Communication." Canadian Chartered Accountant 81 (November 1962):492-96.

Seager, David E. "The Ten Commandments of Forms Design." Canadian Datasystems 9 (October 1977):40-45.

Scheer, Wilbert. "The Art of Writing Business Letters." Office Administration 16(June 1970):96.

--.-. "The Simplified Letter: 01d Style Letters Costly in Time, Money, Goodwi11." Office Administration 13(June 1967):51;64.

Schiele, Robin. "Faster Reading Means Faster Business." Canadian Business 46 (September 1973):68-72;78.

Scott, Robert Ian. The Specific Writer. Toronto: Methuen, 1985.

Scott-Atkinson, D. "How Employees Rate Their Corporate Communications." Marketing 88(February 7, 1983):8-10.

Secord, A. "Idea Communication." Industrial Canada 53(0ctober 1952): 49-50.

Sévigny, Thërèse. "Communications et planification stratégique des ressources humaines." Optimum 13(2)(1982):83-85.

Shave, G. "Business Letters; How to Stay on the Right Lines." Financial Post 73(March 17, 1979):12.

Shephard, D.A. "Learning to Write Well." Canadian Medical Association Journal 116(10)(May 21, 1977):1106-08.

-----. "Medical Writing: Problems and Solutions." Canadian Journal of Surgery 19(6) (November 1976):478-80.

Shore, Elizabeth M. "Yours Bureaucratically': Writing Ministerial Correspondence." Technostyle 4(Summer 1985):44-50.

Simpson, James W. "Organization Charts and Manuals." Canadian Chartered Accountant 79(1961):585-93.

Sipos, George. "A Credible Beginning." Technostyle 1(Fall 1982):13-14.

Skinner, H. "Selling: Good Communication Skills are a Must for Effective Management." Marketing 83(March 20, 1978):24-25.

Sklar, C.L. "Good Communications A Must, Even in the ER." Canadian Nurse 79 (June 1983):51-54.

Sklar, C.L. "When Nurses Fail to Communicate." Canadian Nurse 77 (February 1981):47-48;50-51. 
Soucie, D. "Some Thoughts on How You May Improve Your Communications." Cahper Journal 51 (January-February 1985):48-49.

Stanley, G.A. "How to Improve Your Sales Correspondence." Canadian Business 41 (July 1968): 32-34.

Stickler, A.D. "The Art of Writing." Canadian Chartered Accountant 83 (November 1963):350-53.

"Technical Writing Options-Filling a Need." Literacy Across the Curriculum 1(March-April 1985): 1 .

Terms \& Definitions--A Thesaurus of Information Words. [Toronto]: Ministry of Culture and Recreation, Community Information Services, [1976].

Thomas, B.C. "An Exercise in Communicating a Health Message." Canadian Journal of Public Health $67(5)$ (September-0ctober 1976):387-88.

Thomas, L.B. "So You Want to Write." Country Guide and Nor'west Farmer $57($ March 1938): 48 .

Tremblay, G. $l^{\prime} A B C$ du style publicataire français. Montréal: Linguatech, 1982.

Twaits, W.C. "Communication: 'Getting Your Objectives Across." Industrial Canada 60(JuTy 1959):172-75.

"Two NICB Studies Analyze Cost Cutting and Communications." Canadian Chartered Accountant 88(April 1966):256-57.

"Uniform Requirements for Manuscripts Submitted to Biomedical Journals." Canadian Medical Association Journal 123(11)(December 6, 1980):1095-99.

Université de Montréal. Guide Pour la Présentation et la Rédaction des Proces Verbaux. उe ed. Montréal: Universite de Montréal, Services des Archives, 1978.

Universitē de Montréal. Les Séances des Organismes: La Rédaction des Proces-Verbaux, La Présentation et Le Classement des Documents Afferents aux Seances. Montréal: Services des Archives, Université de Montréal, 1980.

Urquhart, E. (Betty). - "Canadian Forces and Fraser Valley College Co-operate." Technostyle 4(Winter 1985):31-35.

Van Steen, Marcus. "Channel Ideas Your Way." Canadian Business 42(June 1969):24-25;27-28. 
Walter, John A. "Teaching Technical Writing: Resources and Strategies." Technostyle 1(Summer 1982):7-12. [Reprinted from English in Texas, 1980J.

Warner, G. "Practice Talking on Paper If You Want to Write Telling Sales Letters." Marketing 83(May 15, 1978):19-20;22.

"Sales Letter . - When Not to Tell the Whole Story." Marketing 83(May 22, 1978):5;9.

Websdale, $H$. "Beating the Language Barrier." Dimensions in Health Service 59(May 1982):26-27.

Weiner, A. "Stay in Control by Mastering the Art of Listening Well." Executive 25(September 1983):14-18.

White, D.A. "Accounting for Words." Canadian Chartered Accountant 91(July 1967):45-46.

Wilson, Douglas J. "Company Publications: Do Results Justify the Expenditure?" Canadian Business 31(March 1958):102-104.

Wise, Richard M. "Essentials of Valuation Report Writing." CA Magazine 117 (December 1984):66-70; 72-73.

Wright, C.W. "So You're Going to Make a Speech." Canadian Business 22 (October 1949):28-29;80.

"Writing Articles That Are Readable and Saleable." Canadian Doctor 44(March 1978):76-81.

I wish to acknowledge the assistance of Gina Robson in the preparation of this bibliography. 